\title{
Quality Assessment of Groundwater in Mahra, Republic of Yemen
}

\author{
Nagib Ghaleb \\ Department of Civil Engineering, University of Bahrain, Sakheer 1054, Kingdom of Bahrain
}

\begin{abstract}
Groundwater is one of the most important water resources in the world. The groundwater is characterized by relatively stable chemical composition, contains little or no bacteria, and is free from colour, turbidity and suspended solids. However, ground water often contains high concentrations of dissolved iron, manganese and other minerals from the ground layers through which the water has passed. The paper deals with the quality assessment of groundwater in Mahra Governorate, Republic of Yemen and the sustainable management of water resources. Two samples of groundwater were collected from two different wells surface located in Qashen Directorate in Mahra governorate. The analyzed parameters are pH, conductivity, TDS (Total Dissolved Solid), turbidity, total alkalinity, T. Hardness, nitrate, calcium, magnesium, chloride, sodium, florides, iron, manganese, sulfate, phosphate, ammonia, sulfide total coliforms, fecal coliforms. The obtained results showed high concentration of total hardness, calcium, magnesium, sulfate, TDSs, EC (Electrical Conductivity), total coliform and fecal coliforms bacteria more than the Yemeni standards, which could be a result of using cesspits in the studied area by the residents. Hence, a construction of wastewater collection systems and wastewater treatment plant has to be built urgently to avoid water pollution in the studied area.
\end{abstract}

Key words: Water quality, assessment, groundwater.

\section{Introduction}

Groundwater refers to all the water occupying the voids, pores and fissures within geological formations, which originated from atmospheric precipitation either directly by rainfall infiltration or indirectly from rivers, lakes or canals. Sands, gravel, sandstones and limestone formations are the usual sources of groundwater supply though some may be drawn from impervious rocks such as granite when they have an over burden of sand or gravel [1]. Groundwater is a valued fresh water resource and constitutes about two-third of the fresh water reserves of the world [2]. Buchanan [3] also estimated the groundwater reservoir of the world at about $5.0 \times 10^{24} \mathrm{~L}$, this volume is more than 2,000 times the volume of waters in all the world's rivers and more than 30 times the volume contained in all the world's fresh water lakes [3]. Groundwater is used

Corresponding author: Nagib Ghaleb, Ph.D., assistant professor, research field: water supply and environmental engineering. for agricultural, industrial and domestic purposes. It accounts for about $50 \%$ of livestock and irrigation usage and just under $40 \%$ of water supplies, whilst in rural areas, $98 \%$ of domestic water use is from groundwater [4]. Utilization of groundwater as a source for domestic, municipal, agricultural and industrial activities continues to increase principally because of the heavy capital outlay and maintenance of surface water development through dams especially in developing countries [5]. Another factor which is responsible for the attention being diverted to this source is improved technology manifested by deep boring in form of borehole which satisfies WHO (World Health Organization) drinking water quality standard [6]. Groundwater is abstracted through hand-dug wells; hand-pump operated shallow-wells and submersible pump operated deep well or boreholes [7]. Groundwater is often high in mineral content such as magnesium and calcium salts, iron and manganese depending on the chemical composition of the stratum through which the rock flows [8]. 
Yemen has no rivers and fully relies on groundwater and rainwater. However, the main water resource in Yemen is groundwater. The renewable groundwater is estimated to be $1.5 \times 10^{8} \mathrm{~cm} /$ year, which comes predominantly from infiltration in the main wadi beds. Most of the water is withdrawn from groundwater-springs, wells, boreholes - and this has led to serious groundwater depletion as withdrawals far exceed annual groundwater recharge [9].

The sources of wastewater are varied, and with this diversity, the pollutants they contain and the diseases that may cause them increase. Therefore, treatment and purification of that water must be carried out before it reaches the sources of drinking water. Mahra Governorate relies completely on groundwater, but this resource becomes polluted due to mixing with wastewater coming from cesspits. Unfortunately, Mahra Governorate lacks many projects, including the wastewater collection system and wastewater treatment plant. The wastewater is disposed to cesspits. This way of disposal caused mixing of wastewater with groundwater that polluted the groundwater. This led to the presence of pools and swamps due to the flood of cisterns built for each single house independently. This pollution was noticed in the tested samples, which indicated the presence of total and fecal coliform bacteria. The paper aims to evaluate the quality of groundwater in Mahra governorate, Yemen.

\section{Sample Collection and Laboratory Analysis}

A 300-mL desunfected glass bottle was used to collect the groundwater samples.

\section{Results and Discussions}

\subsection{Chemical Characteristics}

The values of measured chemical parameters of groundwater sample from Qashen area in Mahra governorate are presented in Table 1.

The values of total hardness, calcium, magnesium and sulfate are with high concentration. These parameters with high concentration may be due to proximity of the area studied to cesspits of the residents. The values of the other parameters examined such as total alkalinity, chlorides, sodium, fluorides, iron, manganese, nitrate, phosphate and sulfide are within the range of recommended local standard of Yemeni guideline for water quality.

\subsection{Physical Properties}

The values of measured physical parameters of groundwater sample from Qashen area in Mahra governorate are presented in Table 2.

Table 1 Chemical properties of groundwater samples.

\begin{tabular}{llllll}
\hline Parameter & Symbol & Unit & Sample 1 & Sample 2 & Yemeni limits \\
\hline Total hardness & $\mathrm{CaCO}_{3}$ & $\mathrm{mg} / \mathrm{L}$ & 960 & 972 & $100-500$ \\
Calcium & $\mathrm{Ca}^{2+}$ & $\mathrm{mg} / \mathrm{L}$ & 632 & 645 & $75-200$ \\
Magnesium & $\mathrm{Mg}^{2+}$ & $\mathrm{mg} / \mathrm{L}$ & 196.8 & 172.9 & $30-150$ \\
& $\mathrm{CaCO}_{3}$ & $\mathrm{mg} / \mathrm{L}$ & 495 & 505 & $150-500$ \\
Total alkalinity & $\mathrm{HCO}_{3}{ }^{-}$ & $\mathrm{mg} / \mathrm{L}$ & 603.9 & 612.4 & $200-600$ \\
& $\mathrm{CO}_{3}{ }^{2-}$ & $\mathrm{mg} / \mathrm{L}$ & 294 & 68 & $200-400$ \\
Chlorides & $\mathrm{Cl}^{-}$ & $\mathrm{mg} / \mathrm{L}$ & 63 & 0 & $0.5-1.5$ \\
Sodium & $\mathrm{Na}^{+}$ & $\mathrm{mg} / \mathrm{L}$ & 0 & 1.01 & $0.3-1.0$ \\
Fluorides & $\mathrm{F}^{-}$ & $\mathrm{mg} / \mathrm{L}$ & 1.2 & 0.5 & $45-50$ \\
Iron & $\mathrm{Fe}^{2+}$ & $\mathrm{mg} / \mathrm{L}$ & 0.8 & 16 & $200-400$ \\
Nitrate & $\mathrm{NO}_{3}{ }^{-}$ & $\mathrm{mg} / \mathrm{L}$ & 18 & 611 & $0.4-5$ \\
Sulfate & $\mathrm{SO}_{4}^{2-}$ & $\mathrm{mg} / \mathrm{L}$ & 620 & 1.92 & 0.1 \\
Phosphate & $\mathrm{P}_{2} \mathrm{O}_{2}$ & $\mathrm{mg} / \mathrm{L}$ & 1.8 & 0.11 & 0.2 \\
Ammonia & $\mathrm{NH}_{3}$ & $\mathrm{mg} / \mathrm{L}$ & 0.1 & & \\
Sulfide & $\mathrm{S}^{2-}$ & $\mathrm{mg} / \mathrm{L}$ & 0.1 & &
\end{tabular}


Table 2 Physical properties analysis of groundwater sample.

\begin{tabular}{llll}
\hline Parameter & Unit & Groundwater sample & Yemeni limits \\
\hline TDS (Total Dissolved Solids) & $\mathrm{mg} / \mathrm{L}$ & 5,150 & 1,500 \\
EC (Electrical Conductivity) & $\mu \mathrm{S} / \mathrm{cm}$ & 7,920 & 2,500 \\
Temperature & ${ }^{\circ} \mathrm{C}$ & 27 & 25 \\
Turbidity & $\mathrm{NTU}$ & 0.01 & 5 \\
$\mathrm{pH}$ & & 7.44 & $7-9.2$ \\
\hline
\end{tabular}

Table 3 Microbiological properties analysis of groundwater.

\begin{tabular}{llll}
\hline Parameter & Unit & Groundwater sample & Yemeni limits \\
\hline Total coliforms & CFU/100mL & 60 & $<10 \mathrm{CFU} / 100 \mathrm{~mL}$ \\
Fecal coliforms & $\mathrm{CFU} / 100 \mathrm{~mL}$ & 13 & $<10 \mathrm{CFU} / 100 \mathrm{~mL}$ \\
\hline
\end{tabular}

The values of TDSs and EC are with high concentration. This may be due to proximity of the area studied to cesspits of the residents. The values of the other parameters investigated such as turbidity and $\mathrm{pH}$ are within the range of recommended local standard of Yemeni guideline for water quality.

\subsection{Microbiological Analysis}

The values of measured microbiological parameters of groundwater sample from Qashen area in Mahra governorate are presented in Table 3.

The results of microbiological parameters analysis show that the water sample contains high concentration of total coliform and fecal coliforms bacteria indicating pollution of groundwater. This pollution most probably is due to leak of wastewater from the cesspits of the homes.

\section{Conclusion}

Unfortunately, no wastewater collection systems and wastewater treatment plants in the studied area so far. This is the great challenge for the local municipality there. The groundwater is the main source in Mahra governorate. The results obtained showed that, chemical, physical and microbiological properties of groundwater are affected by the presence of the plantations of the residences. The high concentration levels of total hardness, calcium, magnesium, sulfate, TDS, EC, total coliform and fecal coliforms bacteria than the Yemeni standards could be a result of proximity of the studied area to the cesspits of the residents. Hence, the municipal authorities in Mahra governorate should solve the problem urgently by constructing wastewater collection systems and wastewater treatment plant.

\section{References}

[1] Ojo, O. I., Otieno, F., and Ochieng, G. 2012. "Groundwater: Characteristics, Qualities, Pollutions and Treatments." International Journal of Water Resources and Environmental Engineering 4 (6): 162-70.

[2] Chilton, J. 1992. "Women and Water." Waterlines J. 2 (110): 2-4.

[3] Buchanan. 1983. "Ground Water Quality and Quantity Assessment.” J. Ground Water pp. 193-200.

[4] Todd, K. 1980. Groundwater Hydrology (2nd ed.). New York and Chichester: John Wiley \& Sons.

[5] Sangodoyin, A. Y., and Agbawhe, O. M. 1991. "Environmental Study on Surface and Groundwater Pollutants from Abattoir Effluents." Bioresource Technology 41: 193-200.

[6] Osot. 2000. Osot Report on PTF Sponsored National Rural Water Supply Schemes.

[7] Ojo, O. I. 2002. Construction and Maintenance of Borehole in Anambra State (PTF Sponsored Project Experience) M.Sc. Seminar Report University of Ibadan. Department of Agricultural and Environmental Engineering.

[8] Todd, K. 1980. Groundwater Hydrology (2nd ed.). New York and Chichester: John Wiley \& Sons.

[9] Evans, C. A., Coombes, P. J., and Dunstan, R. H. 2006. "Wind, Rain and Bacteria: The Effect of Weather on the Microbial Composition of Roof-Harvested Rainwater." Water Res. 40 (1): 37-44. 